UDC 811.161.1'373.217(23)

DOI https://doi.org/10.32841/2409-1154.2020.44.41

\author{
Nagaitseva N. I., \\ Candidate of Philology, Professor, \\ Professor at the Department of Humanities \\ National Technical University "Kharkiv Polytechnic Institute" \\ Romanov Yu. O., \\ Candidate of Philology, Associate Professor, \\ Associate Professor at the Department of Humanities \\ National Technical University "Kharkiv Polytechnic Institute"
}

\title{
PARTICIPLES AND ADVERBIAL PARTICIPLES IN TEACHING RUSSIAN AS A FOREIGN LANGUAGE
}

Summary. This article considers participles and adverbial participles, the extremely complex and specific phenomena, though scarcely highlighted in programs on teaching Russian as a foreign language (RFL). It is quite clear that an immersion in participles and adverbial participles cannot be superficial; they require non-standard approaches to their presentation.

In RFL teaching, it is important to follow the theoretical foundations acccording to which participles and adverbial participles are understood as special hybrid parts of speech that synthesize some of semantic, morphological, and syntactic features of a verb and adjective (participles), verb and adverb (adverbial participles).

The features of adverbial participles to be taken into account are followings: "second predicate" role, i.e. ability to express additional action of the same subject; irregular way of formation; influence of verbal aspectual and temporal factors exerted on the grammatical meaning; adverbial participial phrase peculiarities; obsolete forms of perfect adverbial participlesж occasional adverbial participle formation.

The peculiarities of participles to be placed the emphasis on are: they receive the category of transitivity / intransitivity and voice meanings from the productive verbs (but the forms for expressing voices (active and passive) in verbs and participles are different), and the features expressed by participles are temporary in contrast to the permanent features expressed by adjectives; there are full and short forms of participles; participle clauses (participles with dependent words) are easily replaced by synonymous definitive subordinate clauses with connective word которьй; in a system of participles, loss of affiliation with verb may occur; occasional participles, often present in literary texts, require special learners' attention.

Thus, adverbial participles and participles are to be considered living and promising parts of speech of modern Russian language widely used both in artistic works and in the language of science.

Key words: participles, adverbial participles, parts of speech, Russian as a foreign language, L2 learning and teaching.

Introduction. Russian participles and adverbial participles can be referred to extremely complex and specific phenomena though scarcely highlighted in programs on RFL [7]. This may be due not only to a shortage of study time caused by the late arrival of students, but also to so called "methodological expediency" giving priority consideration to studying other content words because their higher frequency of use compared to participles and adverbial participles.

However, by virtue of this approach, gaps violating the integrity of the Russian language system itself, where necessary and obligatory segments are the participles and adverbial participles, will inevitably form. It is necessary to take into account their originality and fluctuations in the frequency of use according to the style, as well as the fact that participles and adverbial participles with dependent words are semi-predictive units which are potentially capable of becoming predicative, i.e. sentences.

Despite fundamental differences between participles and adverbial participles (in meaning, form, functioning), they have a single etymological core that goes back to the verb and, on the other hand, possess properties of the second part of speech (participle - properties of the adjective, adverbial participles properties of the adverb). In this regard, an immersion in participles and adverbial participles cannot be superficial (quick formation of skills only for their reception and correct production); they require non-standard approaches to their presentation.

Review of literature. In RFL teaching, we follow the theoretical foundations acccording to which participles and adverbial participles are understood as special hybrid parts of speech that synthesize some of semantic, morphological, and syntactic features of a verb and adjective (participle), verb and adverb (adverbial participles) [4]; Russian adverbial participles are considered to be an independent grammatical category (part of speech) characterized by a pronounced syntactic function, unity of the grammatical form and grammatical meaning made up as a result of a long historical development [1].

In A Reference Grammar of Russian (Cambridge University Press), participles in "the usual sense of participles" are called "adjectival" and деепричастия are called "adverbial" [9, p. 95].

Offering learners a number of exercises aimed at training their skills in participle formation, English-speaking authors try to use equivalent explanations ("present active participle", "past active participle", "imperfective passive participle", "perfective passive participle", "long-form (attributive) participle", "shortform participle") [10], however it should be noted that although the solution to the issue of providing students with comparative information (i.e., comparison of the Russian-language picture with the pictures of the native language of students in a monolingual group, as well as information about other languages they know) 
is the prerogative of the teacher, in some cases, this kind of information is not useful when studying the topics "Russian verb Aspects" and "Participles and Adverbial Participles" [3].

A study of the prosaic texts by A. Pushkin shows that usage of active and passive participles, advervial participles in indefinitepersonal sentences create detachment and objectivity characteristic of a scientific text. The use of finite verbs and participles builds a dynamic picture in prose influencing the reader. All this demonstrates the selection of language tools to perform a pragmatic task in accordance with the needs of society in creating texts of different genres [8].

In particular, it is known that participles are one of the most common verb forms in the written language of science. Experience in creating a dictionary of Russian verbs and verbal forms on the text material of disciplines of engineering profile (mathematics, physics, theoretical mechanicsnics, electrical engineering, descriptive geometry, theory of structural materials, etc.) showed that the total number of participles in sublanguages of these disciplines amounted to1483 lexical units. [2].

The purpose of this study is to provide guidance on what to be taken into account to prepare learning materials [5-6] aiming at development of learners' skills in participle and adverbial participle acquisition.

Main body of the research. Adverbial participle is a specific verbal formation which also has the property of an adverb.

From the verb, adverbial participle borrowed: common lexical meaning; verbal aspect and active voice; verb government of the same case-form and compatibility with the same adverbs as the motivating verb.

Adverbial properties are the absence of inflection and functioning in the sentence as an attribute of predicate.

It is important to learn the followings.

1. Adverbial participle is the "second predicate", i.e. expresses additional action of the same subject.

2. Formation of adverbial participles from verbs is irregular, therefore it is necessary to know that adverbial participles are not made from imperfective verbs as follows: 1) with suffix -нy (сохнуть); 2) not having sonants in the stem of present tense (nьюm); 3) having sounds $[3],[c],[\mathrm{cm}],[x]$ in the stem of infinitive, and at the end of the stem of present tense - hissing sounds (nucamb - numym, махать-мамут); 4) with the infinitive in - $\iota_{b}$ (мочь).

3. It is necessary to take into account the influence of verbal aspectual and temporal factors exerted on the grammatical meaning. Thus, from imperfective verbs, adverbial participles of present tense are formed, and from perfect verbs, adverbial participles of past tense are formed. In the sentence itself, the main verb in the form of the past tense provides adverbial participles additional meaning of cause, and the verb in the form of the future tense - additional meaning of condition.

We also focus on the semantics, indicating the simultaneity or sequence of actions of the first and "second" predicates in one sentence, depending on the type.

4. Adverbial participle with dependent words forms an adverbial participial phrase the specificity of which is in the synthesis of the main and secondary parts (predicate and adverbial modifier) making it capacious and expressive, capable to transform into a fullfledged predicative unit (subordinate clause). However, the degree of predicativity of adverbial participial phrases is different. So, adverbial participial phrases with the meaning of time, concession, condition, and reason are more predictive than the ones with the meaning of manner and are easily replaced by subordinate clauses with corresponding meanings. Learners' practical skills related to implementing such a syntactic substitution should be automated.

5. For humanities majors, knowledge about obsolete forms of perfect adverbial participles may be useful. There are: 1) adverbial participles ending in $-a /$ - $я$ (instead of -8 ), now peculiar to the imperfect adverbial participles. From the etymological point of view, this indicates a later formation of perfect participles. Cf.: усльтиа суд, погубя покой, заглуша ужас instead of усльтав, погубив, заглушив. On the other hand, in fiction texts, there are also imperfect adverbial participles with suffix -8 (instead of $-a /-a$ ): НоЛенский, неимев, конечно, Охотыузыь раканесть, СОнегиным желал сердечно Знакомство покороче свесть (Пушкин); 2) quite obsolete and nowadays excessive suffix of perfect adverbial participles - -uu introducing an undertone of colloquiality; 3) archaic suffixes of imperfect adverbial participles -учи /-юючи also colloquial; 4) remaining verb suffix $-\mu y$ in perfect adverbial participles: остынувши (сf.: остыв); 5) such forms as ушед, бывии (сf.: уйдя, будучи); 6) adverbial participles from archaic verbs: браздя, изрывая, зря (В полях кровавых Марс страшился, Свой меч в Петровых зря руках (Лермонтов)); 7) adverbial participles derived from verbs potentially incapable, nowadays, of providing such formation: петь - поя, ждать -ждя, есть - евщи, едя; 8) adverbial participles derived from verbs which lost part of their lexical meaning: demu $<\ldots .>$ Брать дань богатее задумали с морей, Не рыбой, - жемчугами; И, зная плавать и нырять, Ту подать доправлять Пустились сами (Крылов) (сf.: умея плавать и нырять).

6. Occasional adverbial participles in poetry are quite frequent, and they are perceived as lexical findings by talented authors since they help not only color the text, but also make it semantically unique, requiring mandatory penetration into the essence of associations constructed by the author.

Here are just a few literary illustrations of this phenomenon from poetic texts: Жили, жря и ржа. Лишь наживая, жря и спя, капитализм разбух и обдряб. Себя с врагом померьте, дорогу кровью рдя; до самой небьей тверди коммуну утвердя (Маяковский) (осcasional adverbial participle formation from verbs non-productive to derivation of adverbial participles); Hapodbl, живиие, въямясь в нужду (Маяковский) (сf.: находясь в яме нужды) (occasional adverbial participle formation from verbs derived from nouns); В винниикой глуши тьмутараканясь, так я рисовал, так мне представлялся стопрочентный американеи (Маяковский) (occasional adverbial participle formation from verbs derived from proper names); А на завтра днём меж домов пятиярусных К магазину «Ювелир М. Гуревич и сын» Подкатил. Грузовик. Содрогаясь. Яростно. Волоча. Потроха. У мускулистых. Шин (Сельвинский) (parceled use of single adverbial participles).

In literary texts of the 20th century, occasional is the use of adverbial participles with obsolete suffixes - $a /-я-и и,-у ч и / ю ч и$ : тиранит ревностью всякий пустяк и мерит любовь на калибр револьверный, неверной в затылок пулю пустя (Маяковский) (cf.: пустив); Стоит буржуй, как пес голодный, Стоит безмолвный, как вопрос. И старый мир, как пес безродный, Стоит за ним, поджавши хвост (Блок) (cf.: поджав); Любить - это значит <...> рубить дрова, силой своей играючи (Маяковский) (сf.: играя). 
Participle is a verb form found in different languages (for example, in Romance and Germanic Languages), but in Russian it differs sharply from similar forms in other tongues. Therefore, when studying participles, a foreign learner may experience some difficulties that should be prevented.

1. Russian participles are connected with the narrative of hybridity, i.e. they have grammatical properties of verb and nomen. From the verb, participles inherit same lexical meanings and grammatical properties - aspect, tense, voice (but aspectual and tense paradigms of participles do not coincide with the verbs'). Participles receive the category of transitivity / intransitivity and voice meanings from the productive verbs (but the forms for expressing voices (active and passive) in verbs and participles are different).

Participles borrowed from adjectives variability by gender, number, and case, as well as ability to show agreement with nouns. Moreover, the features expressed by participles are temporary in contrast to the permanent features expressed by adjectives (сf.: читающий / читавщий студент - новый студент).

2. Participles, like adjectives, have full and short forms. Full active participles change similar to adjectives with the stem ending in the hissing consonant (stress on the stem), and passive participles change similar to adjectives with the stem ending in the pairedsolid consonant (cf.: читаюший, читавщий - читаемьй, прочитанный). Short forms are made almost exclusively from past passive participles. At the same time, in the sentence, full and short forms function differently.

3. Participle with dependent words forms participial phrase a semi-predicative unit (with its own word hierarchy) which has a relative semantic independence. Therefore, participle clauses are easily replaced by synonymous definitive subordinate clauses with connective word который, какой taking the form of Nominative / Accusative case depending on whether the active or passive participle is the main one in the participial phrase. Participles of participle phrases agree with the nouns to which they relate.

4. In a system of participles, loss of affiliation with verb may occur, as well as formation of homonyms-adjectives, which is marked in spelling (cf.: Мыслли студентов были сосредоточены на экзамене. - Студенты были серьезны и сосредоточены.). Adjectivization also develops when participle appears to have a figurative meaning (cf.: блестящий металл - блестящий учёный). Substantivization is frequent too: Вспомним с нами отступавщих, Воевавщих год иль час, Павших, без вести пропавщих, $C$ кем видались мых хоть раз, Провожавиих, вновь встречавиих, Нам попить воды подавших, Помолившихся за нас (Твардовский).

Humanities majors learning classical Russian literature may encounter obsolete forms of participles: 1) participles which don't agree with the nouns: Нигде я ничего не внемлю, Кроме ревущия волны (Державин) (inflection -ия (Genitive case, feminine gender, singular) in the Church Slavonic language corresponds to modern inflection -ей: cf.: кроме ревущей волны); 2) аросоріс participles (similar to short forms) which are attributes of nouns: Люблю я пытшное природы увяданье <...> И.малой волнистою покрыты небеса (Пушикин) (сf.: покрытые); 3) participles formed from obsolete verbs: O ты, чьей памятью кровавой Мир долго, долго будет полн, Приосенён твоею славой <... (Пушкин), И вот, бессмертные на время, Мык клику сосен причтены И от болей и эпидемий И смерти освобождены (Пастернак).

5. Occasional participles, often present in literary texts, require special learners' attention: кольббелимые пылью шоссе; Вы себе представляете парижских женщин с шеей разжемчуженной, разбриллиантенной рукой... ; выюиревший лакей; глаза наслезнённые; Каждый дюйм бытия земного профамилиен и разыменован (Маяковский).

These unique words and word forms are created with the help of: 1) word-building: громокипящий кубок (Северянин), звонкобегущие ручьи (Лермонтов); 2) word combinations creating an unexpected effect: щарахнутые бунта веником лавочники, непрожёванный крик, Слушайте ж, забывшие, что небо голубО, выщетинивщиеся, звери точно! (Маяковский); 3) grammatical means (formation of a short form from present active participles): Человек непонятен $B$ поступках своих: Он прекрасен, Ужасен, Грохочущ И тих (Дмитриев).

Conclusions. Thus, adverbial participles and participles are to be considered living and promising parts of speech of modern Russian language. Successful teaching and learning Russian adverbial participles and participles will require the support of the following: 1) consideration of their creative properties; 2) formation of necessary skills in their word formation associated with aspect and tense system; 3) acqusition of paradigms of full and short participles, as well as their functioning in the sentence; 4) automation of transformations of active structures with participles in passive and vice versa; 5) skills in replacements of semi-predictive units with predicatives (subordinate clauses); 6) optional presentation of obsolete and occasional adverbial participles and participles, as well as associated extension of work with them; 7) finally, a comparative study of adverbial participles and participles with a probable delayed effect.

\section{References:}

1. Абдулхакова Л.Р. Русское деепричастие: часть речи или форма глагола? Вестник Волгоградского государственного университета. Серия: Языкознание. 2010. № 2. С. 67-72.

2. Васильева Т.В. Опыт создания словаря русских глаголов и глагольных форм на материале текстов дисциплин инженерного профиля. Научный Вестник Московского государственного технического университета гражданской авиации. Серия: Международная деятельность высшей школьл. 2006. № 102. С. 82-90.

3. Грекова О.К. Презентация темы «Виды глагола и отглагольные формы» в тестах ТРКИ (А1-А2-В2). Мир русского слова. 2016. № 4. C. $97-104$.

4. Киров Е.Ф. Части речи русского языка. Вестник Нижегородского университета им. Н.И. Лобачевского. Серия: Филология. 1999. № 1. С. 31-58.

5. Нагайцева Н.И. Деепричастие: Учебное пособие по русскому языку для иностранных студентов. Харьков : НТУ «ХПИ», 2019. 124 с.

6. Нагайцева Н.И. Причастие : Учебное пособие по русскому языку для иностранных студентов. Харьков : НТУ «ХПИ», 2020. 140 с.

7. Программа по русскому языку для студентов-иностранцев основных факультетов высших учебных заведений Украины III-IV уровней аккредитации / сост. Н.И. Нагайцева, Т.А. Снегурова, С.Н. Чернявская и др. 3-е изд., доп. Харьков, 2014. 60 с.

8. Пушкарева Н.В. Семантика и прагматика глагольных форм в прозаических текстах А.С. Пушкина. Ученые записки Петрозаводского государственного университета. Серия: Языкознание. 2020. T. 42. № 1. C. 92-96. DOI: 10.15393/uchz.art.2020.438.

9. Timberlake A. A Reference Grammar of Russian. New York : Cambridge University Press, 2004. 503 p.

10. Wade T. Russian Grammar Workbook. Hoboken: John Wiley \& Sons, Incorporated, 2013. 254 p. 
Нагайщева Н. І., Романов Ю. О. Дієприкметники і дієприслівники у викладанні російської мови як іноземної

Анотація. У статті розглянуто дієприкметники та дієприслівники - надзвичайно складні та специфічні явища, недостатньо висвітлені у програмах викладання російської мови як іноземної (РЯІ). Цілком зрозуміло, що занурення у вивчення дієприкметників та дієприслівників не може бути поверхневим; вони вимагають нестандартних підходів до їхнього викладання.

У викладанні РЯІ важливо дотримуватися теоретичних уявлень, згідно з якими дієприкметники та дієприслівники вважають особливими гібридними частинами мови, що синтезують деякі семантичні, морфологічні та синтаксичні особливості дієслова та прикметника (дієприкметники) і дієслова та прислівника (дієприслівники).

Особливості дієприслівників, які слід враховувати під час викладання, $є$ такими: роль дієприслівника як «другого предиката», тобто його здатність відбивати додаткові дії того самого підмета; нерегулярний спосіб формування; вплив дієслівних видових та часових факторів на граматичне значення; особливості дієприслівникових зворотів; застарілі форми дієприслівників доконаного виду; утворення оказіональних дієприслівників.
Особливості дієприкметників, на які слід акцентувати увагу, полягають у тому, що: вони отримують категорію транзитивності / інтранзитивності та станові значення від продуктивних дієслів (але форми вираження стану (активного та пасивного) у дієсловах та дієприкметників різні), і ознаки, виражені дієприкметниками, є тимчасовими, на відміну від постійних ознак, виражених прикметниками; існують повні та короткі форми дієприкметників; дієприкметникові звороти (дієприкметники із залежними словами) легко замінюються синонімічними підрядними реченнями зі сполучним словом который; у системі дієприкметників може статися втрата приналежності до дієслова; оказіональні дієприкметники, що часто присутні в літературних текстах, потребують особливої уваги.

Таким чином, дієприслівники та дієприкметники слід вважати живими та перспективними частинами сучасної російської мови, що широко використовуються як у художніх творах, так і в науковому мовленні.

Ключові слова: дієприкметники, дієприслівники, частини мови, російська мова як іноземна, вивчення і викладання другої мови. 